\title{
KAJIAN PENGELOLAAN BIAYA DALAM SISTEM PENGANGGARAN
}

\author{
Intisari
}

Secara de jure, amanat pelaksanaan performance based budget telah berumur lebih dari satu dekade tertulis dalam UU 17 tahun 2003. Secara de facto, bisa jadi belum seperti harapan. Kondisi ini disinyalir karena dalam proses penganggaran masih terjebak dalam detail per item belanja, termasuk didalamnya upaya penerapan prinsip let the manager manage yang masih sarat dengan pendekatan line item.

Kajian ini berupaya memaparkan peran strategis costing dalam mewujudkan tujuan performance based budgeting beserta langkah merealisasikannya. Kajian ini menggunakan metode telaah literatur, peraturan yang ada dilakukan analisa dan dituangkan dalam pemikiran untuk pengembangan penerapannya khususnya dalam sisi pengelolan biaya.

Pada akhir Kajian ini, ditekankan bahwa perbaikan pengaturan costing melalui standar biaya yang disempurnakan dari waktu ke waktu adalah modal dasar dalam mewujudkan efisiensi di level alokasi dan pelaksanaan dalam kesatuan sistem penganggaran.

Kata kunci: biaya, performance based budget, standar biaya, costing

\section{PENDAHULUAN}

\subsection{Latar Belakang}

Secara yuridis (de jure) kehendak untuk mempraktekkan Performace Based Budgeting telah diamanatkan dalam UU No 17 tentang Keuangan Negara, namun setelah hampir 10 (sepuluh) tahun diundangkan, boleh jadi dalam prakteknya (de facto) masih belum seperti harapan, seperti masih tercampur dengan rasa Line Item Budgeting.

Performance Based Budgeting mensyaratkan bahwa terlaksananya prinsip let managers manage akan berjalan baik manakala: (1) adanya kepercayaan (trust) dari Kementerian Keuangan selaku Chief Financial Officer (CFO) kepada K/L (managers) selaku Chief Operational Officer (COO) untuk mengurus hal-hal yang detail dan mengikat hal-hal yang strategis (capaian output), didasarkan pada anggapan bahwa K/L (managers) adalah pihak yang dianggap paling mengetahui dan paling bertanggung jawab tentang bagaimana cara untuk mencapai output yang diperjanjikan atas penggunaan alokasi anggaran, dan (2) pada saat bersamaan K/L (managers) diasumsikan memang dapat dipercaya (amanah) dalam membelanjakan anggarannya untuk mencapai output yang diperjanjikan secara efisien dan efektif, sehingga apabila dalam pelaksanannya terdapat pelanggaran maka mereka harus dimintakan pertanggungjawabannya.

\subsection{Identifikasi Masalah}

Permasalahan belum sempurnanya penerapan Performance Based Budgeting utamanya karena proses penganggaran yang ada masih sering terperangkap dengan hal-hal detail item-per-item belanja, yang melebihi dari orientasi pada hasil (output) - itu sendiri. Hal lain yang juga ikut memperkeruh kondisi ini adalah 
penerapan prinsip let managers manage pada K/L pada saat pelaksanaan anggaran, yang juga masih sangat kental dengan pendekatan item-item belanja yang sering melebihi dari upaya pencapaian output secara efisien dan efektif.

\subsection{Tujuan}

Kajian ini dimaksudkan untuk memaparkan peran strategis standar biaya (costing) dalam mewujudkan tujuan performance based budgeting, dan langkah-langkah untuk merealisasikannya.

\section{METODOLOGI PENELITIAN}

Kajian ini menggunakan metode telaah literature, peraturan yang ada dilakukan analisa dan dituangkan dalam pemikiran untuk pengembangan penerapannya khususnya dalam sisi pengelolan biaya.

\section{TINJAUAN PUSTAKA}

\subsection{Peranan Standar Biaya}

Upaya untuk mengoptimalkan peran standar biaya (costing) dalam sistem penganggaran perlu berangkat dari pemikiran tentang perlunya mencermati kembali atas pengaturan three in one (satu dan lainnya saling melengkapi, saling menguatkan, dan harus saling bekerja paralel), yaitu antara: (1) indikator kinerja, (2) standar biaya (costing) dan (3) evaluasi kinerja dalam mensukseskan pelaksanaan Performance Based Budgeting.

\section{Gambar 1. Hubungan instrumen penganggaran}

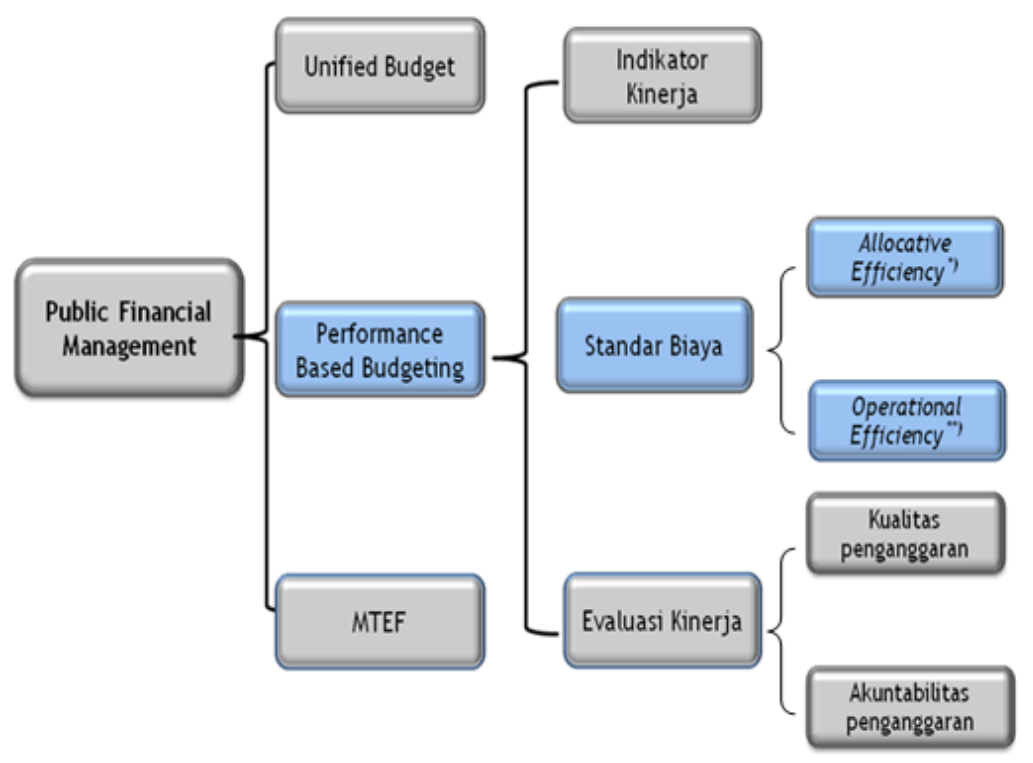

Hubungan ketiga instrumen performance based budgeting tersebut dapat dijelaskan sebagai berikut: Pertama, rumusan output secara tepat beserta indikatornya merupakan cerminan seberapa efektif nantinya akan mampu menopang mencapaian kegiatan, program dan dampak (impacts) dari alokasi anggaran akan dirasa secara riil oleh masyarakat. Hal ini menguatkan keyakinan tentang urgensi untuk mengawal terwujudnya rumusan output dan indikator kinerja $\mathrm{K} / \mathrm{L}$ di tingkat pusat dan SKPD di tingkat daerah dalam suatu 
arsitektur kinerjayang makin baik dari waktu ke waktu. Kedua, standar biaya (costing) merupakan pengisi rumah struktur program sebagai alat agar alokasi anggaran dapat dilakukan secara efisien dan ekonomis dalam pencapaian output. Hal ini mengedepankan pentingnya allocative efficiency dalam perencanaan anggaran dan operational efficiency dalam pelaksanaan anggaran dengan menggunakan prinsip let managers manage. Sedangkan ketiga, evaluasi kinerja yang dilaksanakan melalui monitoring dan evaluasi (monev) menjadi pilar/alat untuk mengawal dan membandingkan antara pelaksanaan anggaran dengan tujuan kinerja yang diharapkan dari alokasi anggaran agar dapat terlaksana sesuai dengan yang telah diperjanjikan dalam indikator kinerja output sampai dengan impact kepada masyarakat. Dari ketiga instrumen tersebut selanjutnya indikator output dan costing yang memadai diperlukan agar monev dapat berjalan sesuai tujuan. Rumusan output yang tepat dan memadai merupakan prasyarat agar costing dapat dilaksanakan secara baik pada saat proses alokasi anggaran. Selanjutnya, hasil monev juga dibutuhkan untuk proses costing dalam alokasi anggaran periode berikutnya.

\section{Gambar 2. Costing Dalam Penganggaran}

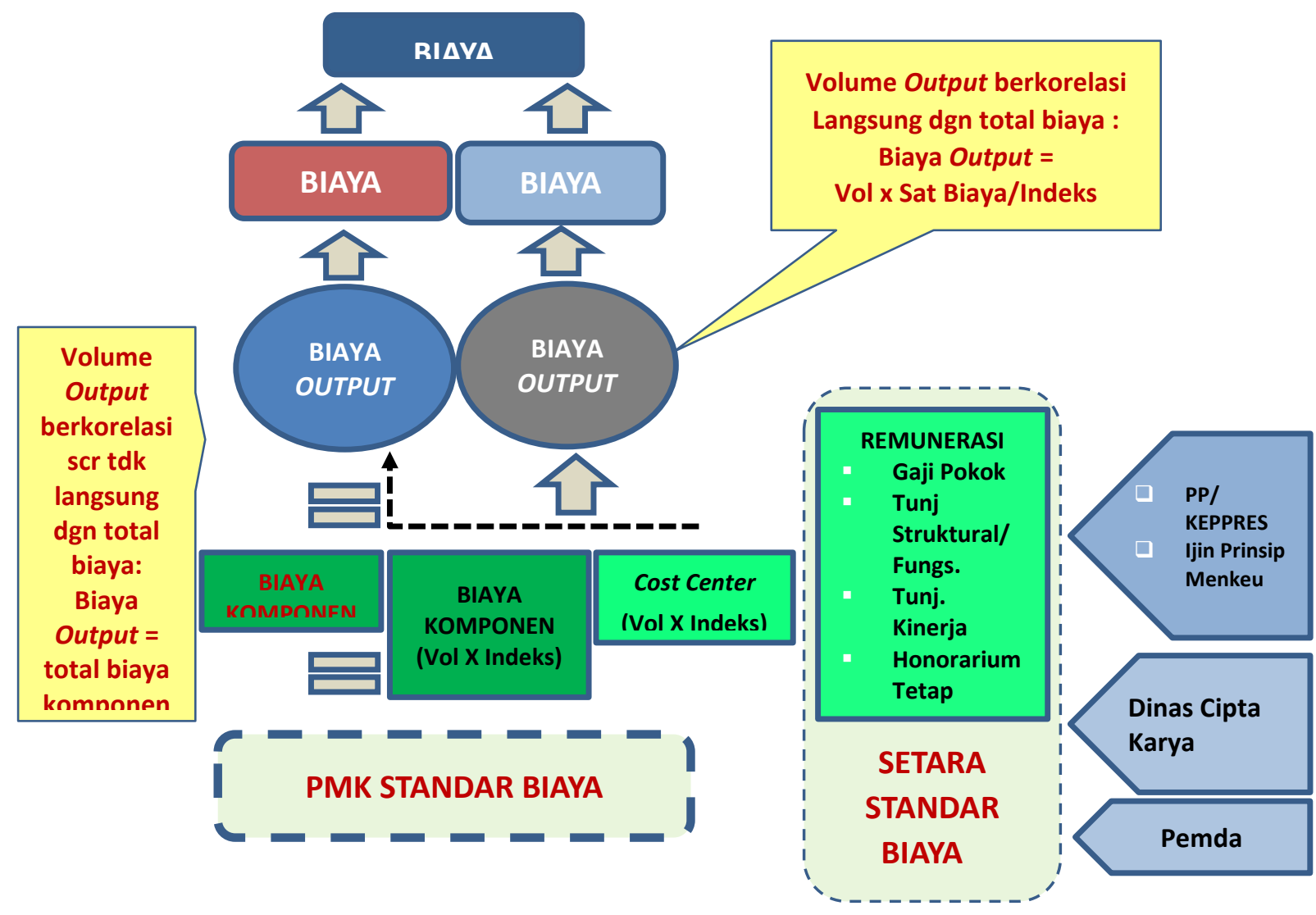

Standar biaya (costing) dalam sistem penganggaran mempunyai peran yang sangat penting untuk menjamin terwujudnya keekonomian dan efisiensi anggaran. Salah satu alasannya adalah karena karakteristik $\mathrm{K} / \mathrm{L}$ dan SKPD (pengguna anggaran) saat ini cenderung untuk menggunakan anggaran dengan 
harga maksimal dan perlunya prinsip keadilan untuk pembiayaan suatu kegiatan/aktivitas yang sama bagi seluruh pengguna anggaran. Untuk mewujudkan peran standar biaya yang makin berkontribusi positif dalam sistem penganggaran, CFO sebagai otoritas perencanaan keuangan $\mathrm{K} / \mathrm{L}$ dan SKPD harus melakukan langkah-langkah dalam menerapkan efisiensi belanja negara, salah satu caranya melalui penetapan standar biaya, yang meliputi: (1) standar biaya masukan (SBM), dan (2) standar biaya keluaran (SBK). Mengingat Standar biaya merupakan instrumen efisiensi dalam penerapan Performance Based Budgeting, maka pengembangan standar biaya (costing) akan diarahkan pada pengembangan standar biaya yang berorientasi pada hasil atau penyusunan standar biaya berbasis output dalam bentuk penyusunan Standar Biaya Keluaran (SBK). Seharusnya SBK secara bertahap dikembangkan ke arah fullcosting (dengan mengecualikan komponen gaji dan biaya administrasi pada tahap awalnya) dengan menggunakan pendekatan activity based costing. Apabila hal ini telah dilakukan, maka alokasi anggaran akan didasarkan pada alokasi biaya output yang dihasilkan oleh $\mathrm{K} / \mathrm{L}$ atau SKPD yang bersangkutan.

\section{PEMBAHASAN}

\subsection{Pengembangan Standar Biaya}

Untuk penerapan standar biaya yang bersuber dari APBN, dalam pasal 3 ayat (1) UU Nomor 17 Tahun 2003 tentang Keuangan Negara diatur bahwa yang dimaksud standar biaya adalah satuan biaya yang ditetapkan baik berupa standar biaya keluaran sebagai acuan perhitungan anggaran dalam RKAKL. Lebih lanjut diatur bahwa standar biaya merupakan salah satu instrument penting dalam penyusunan alokasi anggaran, sebagaimana diatur dalam pasal 5 ayat (3) PP Nomor 90 Tahun 2010 tentang Penyusunan Rencana Kerja dan Anggaran Kementrian/Lembaga, bahwa penyusuaan RKAKL menggunakan instrument indikator kinerja, standar biaya dan evaluasi kinerja. Standar biaya meliputi merupakan satuan biaya yang ditetapkan sebagai acuan penghitungan kebutuhan anggaran dalam Rencana Kerja dan Anggaran Kemetrian Negara/Lembaga, baik berupa Standar Biaya Masukan maupun Standar Biaya keluaran. Standar Biaya Masukan (SBM) adalah satuan Biaya berupa harga satuan, tariff, dan indeks yang digunakan untuk menyusun biaya komponen masukan kegiatan. Sedangkan Standar Biaya Keluaran (SBK) adalah besaran biaya yang dibutuhkan untuk menghasilkan sebuah keluaran kegiatan yang merupakan akumulasi biaya komponen masukan kegiatan.

Untuk pengelolaan biaya dalam proses alokasi dan pelaksanaan anggaran atas kegiatan yang dananya bersumber dari APBN dan APBD perlu adanya pengembangan sistem costing (costing system) secara konsisten dari waktu ke waktu sesuai tuntutan perkembangan jaman. Costing system pada hakekatnya diperlukan untuk melakukan perkiraan jumlah alokasi dana untuk berbagai jenis pengeluaran di dalam suatu K/L atau SKPD. Standar analisis belanja ini perlu dilakukan untuk menghasilkan alokasi anggaran 
berbasis aktivitas yang lebih akurat, sehingga setiap anggaran yang dikeluarkan didasarkan atas proses penghitungan yang wajar dan rasional.

Costing system tersebut diperlukan agar dapat mendorong $\mathrm{K} / \mathrm{L}$ atau SKPD selaku COO untuk melaksanakan prinsip ekonomi, efisiensi dan efektifitas secara berkesinambungan. Costing system diperlukan untuk menjamin implementasi Penganggaran Berbasis Kinerja, dan Kerangka Pengeluaran Jangka Menengah agar dapat berjalan sesuai harapan, yaitu tercapainya keseimbangan ekonomis, efisiensi dan efektivitas. Oleh karena itu, dalam pengembangan pengelolaan biaya disektor publik yang bersumber dari APBN dan APBD perlu dicermati esensi penggunaan pendekatan menerapkan biaya berbasis aktivitas (Activity Based Costing).

Standar Biaya Masukan (SBM) saat ini telah menjadi tools bagi pengguna anggaran dalam melakukan penyusunan dokumen perencanaan anggaran. Selain itu, standar biaya juga diperlukan untuk membatasi pengeluaran-pengeluaran yang terkait dengan tambahan penghasilan bagi pegawai, karena dengan belum berlakunya sistem remunerasi secara penuh, saat ini banyak pengguna anggaran yang masih mengalokasikan honorarorium yang seharusnya sudah menjadi bagian dari sistem remunerasi sehingga perlu pembatasan melalui standar biaya. Sedangkan untuk Standar Biaya Keluaran (SBK), saat ini penyusunannya masih dilakukan hanya untuk biaya langsung (direct cost) yang terkait langsung dalam pencapaian suatu output, dengan fokus pada proses pembelajaran kepada pengguna anggaran bahwa penyusunan SBK merupakan bagian dari upaya efisiensi belanja negara. Namun demikian, pengembangan konsep SBK terus dilakukan secara bertahap agar perubahan yang terjadi dapat berjalan dengan baik dan dapat diterima oleh pihak-pihak yang berkepentingan.

Beberapa hal penting yang merupakan area pengembangan SBM adalah: (1) Peningkatan kualitas dan cakupan SBM, dan mencarikan penataan pengaturan terhadap satuan-satuan biaya yang berlaku spesifik pada setiap pengguna anggaran untuk menjamin efisiensi anggaran, (2) Makin mengintensifkan keterlibatan pengguna anggaran dalam penyusuna SBM, dan (3) Menggeser penggunaan SBM ke pengguna anggaran dengan menguatkan peran aparat pengawasan dalam memantau pelaksanaan SBM oleh pengguna anggaran.

Sedangkan beberapa area pengembangan SBK antara lain dengan cara: (1) Pengembangan costing methodologies, dan (2) pengembangan benchmarking atas SBK yang telah ada untuk diterapkan pada tahun berbeda, wilayah berbeda, atau pengguna anggaran yang berbeda. Kondisi saat ini, SBK sebagai alat efisiensi kurang mendapat tanggapan positif dari pengguna anggaran karena beberapa hal: (1) keengganan pengguna anggaran untuk melakukan efisiensi, (2) Hukum penerapan SBK belum menjadi kewajiban, (3) Pengguna anggaran belum merasa menerima manfaat secara nyata atas penerapan SBK, (4) Yang sudah menerapkan SBK justru merasa sering diaudit daripada yang belum menerapkan 
SBK. Hal-hal tersebut selanjutnya perlu disikapi dengan seksama, dan dituangkan dalam peraturan

\subsection{Langkah-Langkah Pengembangan}

Untuk mencapai tujuan pengembangan standar biaya tersebut di atas, reformulasi pengaturan teknis standar biaya tidak saja dalam bentuk penetapan (besichking) dalam bentuk satuan-satuan biaya dan angka-angka untuk setiap tahunnya, tetapi juga dalam bentuk pengaturan (regelling) yang berupa pedoman mengelola biaya oleh pengguna anggaran yang berlaku untuk jangka lebih panjang. Pengaturan standar biaya yang berlaku untuk sepanjang tahun tersebut mencakup prinsip-prinsip dan pedomanpedoman costing untuk menjamin allocative efficiency dan operational efficiency.

\section{Gambar 3. Pengaturan Standar Biaya}

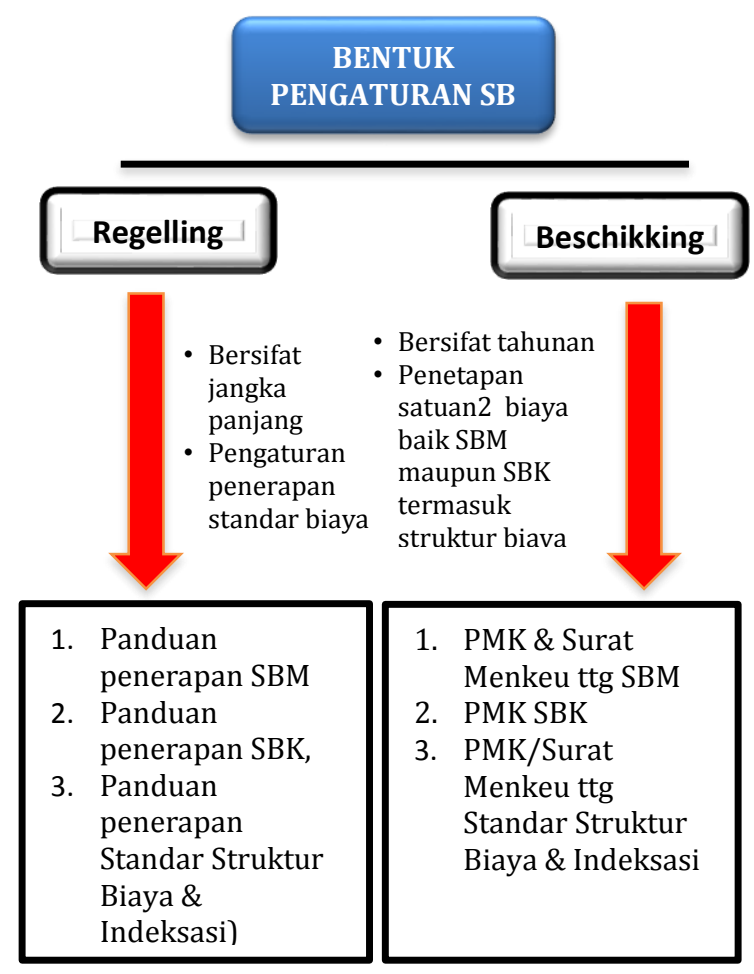

Upaya untuk menjadikan SBK sebagai suatu kewajiban bagi pengguna anggaran merupakan upaya pengembangan yang penting untuk dilakukan. SBK sebagai keharusan tersebut dilakukan untuk ha-hal tertentu secara bertahap melalui proses penelaahan secara prudent yang akan dijadikan sebagai baseline (angka dasar) untuk output-output sejenis. Untuk mendukung proses ini perlu disusun costing methodolgy sebagai proses efisiensi terhadap output-output yang dihasilkan pengguna anggaran. Kalau hal ini sudah tertata, langkah berikutnya adalah alokasi output-output yang bersifat dukungan manajemen (gaji dan manajemen kantor) didistribusikan kepada output-output teknis sehingga yang tersisa adalah output teknis saja sebagai dasar alokasi anggaran setiap pengguna anggaran. Untuk mendukung alokasi output bersangkutan maka perlu pedoman bagaimana suatu output dicapai melalui tahapan-tahapan atau komposisi biaya tertentu sehingga dalam pencapaian suatu output menjadi jelas biaya-biaya yang diperlukan.

Secara lebih rinci, langkah-langkah pengembangan dari aspek kebijakan, sistem dan SDM adalah sebagai berikut:

a. Aspek Kebijakan

Pengembangan standar biaya diarahkan kepada pencapaian keekonomiasan alokasi dan efisiensi belanja negara dalam rangka mendukung penerapan anggaran berbasis kinerja. Untuk pengembangan ini perlu koordinasi secara lebih inten antara CFO dengan COO dan para praktisi penganggaran, khususnya mengenai metodologi 
pembiayaan sebagai upaya untuk mendorong percepatan penerapan SBK.

b. Aspek Kesisteman

Pengembangan standar biaya harus sejalan dengan sistem perencanaan yang berlaku (Renstra, Renja, Penganggaran itu sendiri (RKA-K/L atau RKA SKPD), dokumen pelaksanaan anggaran dan pertanggungjawaban kinerja (LKPP dan LAKIP). Dari aspek kelembagaan, perlu dikaji kembali keberadaan unit yang bertanggungjawab menangani seluruh elemen yang terdapat di dalam Standar Biaya, dan dalam kerangka penerapan full-costing maka upaya untuk mensinergikan penanganan standar biaya dan remunerasi merupakan hal urgent dalam kerangka proses reorganisasi. Dari sisi Teknologi Informasi, perlu dikembangkan Sistem Informasi/Teknologi Informasi (SI/TI) dalam rangka pengolahan data hasil survey dan penetapan besaran standar biaya secara elektronik.

c. Aspek Sumber Daya Manusia

Peningkatan kapasitas SDM yang memadai untuk mengembangkan norma akuntansi biaya pada sektor publik/pemerintahan sebagai upaya penerapan efisiensi atas anggaran berbasis kinerja. Peningkatan SDM dimaksud meliputi SDM padai CFO, COO dan Aparat Pemeriksa Fungsional melalui program intensif semacam PPAKP (pada akuntansi pemerintahan) dengan tekanan pengetahuan proses perencanaan dan costing methodology.

d. Aspek pengembangan kerjasama

Pengembangan standar biaya tidak hanya cukup dilaksanakan sendiri. Perlu adanya upaya-upaya yang lebih strategis dengan memperluas kerjasama dengan pihak lain untuk pengembangannya. Beberapa bentuk kerjasama pengembangan Standar Biaya antara lain dalam bentuk kerjasama terkait costing methodology dengan pihak kampus, pelaksanaan survey dengan BPS dan/atau institusi Kementerian Keuangan yang memiliki kantor daerah, dan terkait capasity building dan bantuan konsultan dapat bekerjasama dengan lembaga-lembaga internasional yang bersedia memberikan bantuan atau hibah untuk kepentingan pengembangan standar biaya tersebut.

\section{PENUTUP}

$$
\text { Upaya-upaya }
$$

percepatan pengembangan standar biaya merupakan salah satu pilar penting dan urgent untuk mewujudkan pencapain tujuan implementasi Performance Based Budgeting. Penerapan Performance Based Budgeting sudah dilaksanakan sejak ditetapkannya UU No 17 tahun 2003, tetapi karena hasilnya masih jauh dari harapan maka saat sekarang dan selanjutnya merupakan momentum penting untuk mewujudkan peningkatan kualitas implementasinya. Pengaturan Standar Biaya yang telah ada saat ini dari waktu ke waktu makin membaik merupakan modal dasar untuk pengembangan standar biaya yang lebih sempurna, agar standar biaya betul-betul menjadi instrumen yang makin efektif dalam mewujudkan allocative efficiency dan operational efficiency dalam sistem penganggaran. 